The Chittagong Univ. J. B. Sci., Vol. 4(1 \&2):01-12, 2009.

\title{
TOXIC RESPONSE OF HETEROPNEUSTES FOSSILIS (BLOCH) TO SOME INDIGENOUS PLANT SEED EXTRACTS
}

\author{
MUNIRA NASIRUDDIN ${ }^{1}$, MONIKA RAHMAN AND ROZINA AKHTER \\ Department of Zoology, University of Chittagong, Chittagong- 4331, Bangladesh
}

\begin{abstract}
Toxic responses of distilled water, 50\% ethyl and absolute ethyl alcohol extracts of six indigenous plants, Datura innoxia (Mill), Clerodendrum viscosum (Vent), Amoora rohituka (Roxb) Wt. et. Arnott, Acacia auriculaeformis A. Cunn. ex. Benth., Pongamia pinnata (L) Pierre and Acacia catechu Willd were studied on a predatory fish Heteropneustes fossilis (Bloch) in laboratory conditions. Amongst the extracts the toxicity range varied, absolute ethyl alcohol extract of $A$. rohituka seeds being the most toxic $\left(\mathrm{LC}_{50}=8.67 \mathrm{ppm}\right)$ whilst distilled water extract of $D$. innoxia seeds was the least toxic $\left(\mathrm{LC}_{50}=1950.03 \mathrm{ppm}\right)$. On the basis of $\mathrm{LC}_{50}$ and relative potency values the relative toxicity of the six plants was in the order- $A$. rohituka $>C$. viscosum $>P$. pinnata $>A$. auriculaeformis $>A$. catechu $>D$. innoxia seed extracts. These six indigenous plant seed extracts assayed might be helpful as controlling agent of undesirable fishes in fish culture ponds.
\end{abstract}

Key words: Toxicity, Plant toxins, Behaviour, Mortality, H. fossilis

\section{INTRODUCTION}

Eradication of predatory fishes is an essential pre-requisite for scientific management of perennial nursery and stocking ponds. Indiscriminate use of synthetic pesticides pollute the aquatic environment affecting aquatic fauna, mainly fishes. Age old, traditionally screened botanical control agents have been used to remove undesirable fishes from the freshwater environments. For total or near total eradication of harmful fishes, a wide range of piscicides derived from plants is employed. Such plant poisons are the safe substitutes as they possess the requisite properties of high potency, easy decomposability and unabated supply.

The plant preparations such as the Derris root powder (Shirgur 1972), Nicotine (Konar 1970, 1977), Rotenone (Haque and Tilton 1970), and Antimycin (Lennon and Berger 1970) have potentiality as fish poison. Powder from the roots

Corresponding author email: maazadi@yahoo.com 
of Balanites roxburgii, seeds of Randia dumertorum, twigs and roots of Derris elliptica and bark of Albizzia lebbeck also have piscicidal effects (Shirgur 1975).

In Bangladesh, a good numbers of herbs, shrubs and plants have piscicidal properties (Ameen and Shahjahan 1987, Ameen et al. 1987, Latifa et al. 1987, 1988, 1992, 1997, 2002, 2004, Latifa and Begum 1993 and Nasiruddin et al. 1997, 1998, 2006). There is need for further research to screen fish toxicants which are safe and useful in aquaculture. In the present study attempts were made to find out whether some of the local plants could be used as effective fish poison. The present study is also concerned with the comparative assaying of extracts of six indigenous plant seeds i.e. Datura innoxia (Mill), Clerodendrum viscosum (Vent), Amoora rohituka (Roxb) Wt. et. Arnott, Acacia auriculaeformis A. Cunn. ex Benth, Pongamia pinnata (L) Pierre and Acacia catechu Willd on a predatory fish, Heteropneustes fossilis (Bloch).

\section{MATERIALS AND METHODS}

Toxic effects of the plant extracts of six indigenous plant seeds of $D$. innoxia (Sada dhutra), C. viscosum (Vat), A. rohituka (Pitraj), A. auricalaeformis (Akashmoni), P. pinnata (Karinja) and A. catechu (Khair) were determined on $H$. fossilis. Every set of predatory fishes $(n=60)$ were collected from city markets of Chittagong city. In the laboratory the fishes were stocked in glass aquarium $(60 \times 30 \times 30 \mathrm{~cm})$ containing tap water and were acclimatized for 4-5 hours. Active and healthy fishes were used for the experiments. The average total length and weight of the fishes were $12.50 \pm 0.21 \mathrm{~cm}$ and $8.69 \pm 0.97 \mathrm{~g}$ respectively.

Dry seeds were weighed in a semi automatic table balance and finely grinded in a grinder. Ten $\mathrm{g}$ of seed powder was mixed in $100 \mathrm{ml}$ of either of distilled water, $50 \%$ ethyl or absolute ethyl alcohol solvents in a conical flask which was shaken vigorously in a magnetic stirrer for 4-5 hours to allow maximum extraction of the toxic components. The extract was filtered through fine muslin cloth and the filtrate was the stock solution prepared on the day of the experiment. The different test concentrations recorded in terms of ppm were calculated from the stock solution by dilution (APHA 1976) such that the total volume in the aquarium was five liters in each of the replicates.

Each final experiment was performed in the laboratory to determine 1090\% mortality in the liquid seed extracts of the six plants against $H$. fossilis. Five concentrations of each extract were bioassayed, each concentration was replicated twice (Latifa et al. 2002) and the test fishes were kept for $24 \mathrm{~h}$. test exposure 


\section{TOXIC RESPONSE OF HETEROPNEUSTES FOSSILIS}

period. In each experiment a control set was similarly maintained. After the release of the fishes behaviour pattern in the highest concentrations was observed. Mortality was counted on those fishes which were killed within $24 \mathrm{~h}$ of exposure at various concentrations of the toxicants.

Mortality data were subjected to probit analysis (Finney 1971) which was used to determine $\mathrm{LC}_{50}$ values of each extract upon the fishes. The values of chisquare were compared with tables of statistics for $n-1$ degrees of freedom at 0.05 level of significance. Analysis of variance of percentage mortality of fishes was made to estimate the variation among treatments at 0.01 level of significance. Relative potency of the equitoxic toxicants was calculated by taking the highest $\mathrm{LC}_{50}$ value of a toxicant as unit and comparing the respective $\mathrm{LC}_{50}$ values of the other toxicants in the study.

\section{RESULT AND DISCUSSION}

\section{Behaviour of control fishes}

The fishes in the control sets showed normal behaviour throughout the experiment. They remained healthy and active with vigorous movement. The fishes swam gently by regular opening of their operculum, with normal barbels and soft fins. All the fishes were physically well-balanced. No control mortality was noticed.

\section{Effects of the seed extracts on the behaviour of the fishes}

When the fishes were exposed to D. innoxia seed extracts, they showed reaction in abnormality within half an hour. They showed up and down movements and regular surfacing for taking air. Gradually their movement slowed down and settled to the bottom. Dead fishes were slimy and pale in colour with stiffened body, straight fins and wavy barbels. Some of the dead fishes floated roughly at $45^{\circ}$ angle to the water surface but most laid at the bottom.

With $C$. viscosum seed extracts, the first visible reaction started within 5 minutes after exposure to the toxicant. The fishes moved vigorously and were very restless. Opercular movements increased and were occasionally surfacing. After an hour their movement became sluggish, lost equilibrium, settled to the bottom and died at different intervals. Profuse pale yellowish slime was secreted. Fins were broken and with droopy barbels. Some of the dead fishes were seen floating parallel to the water surface and some were seen floating at various angles. 
On exposure to A. rohituka seed extracts, the fishes showed immediate reaction. They swam erratically with rapid opercular movement and were found gulping for air. As a result most of the fishes were seen near the surface. The fishes became paralyzed within an hour and finally dropped to the bottom. Most of the time they remained immutable. The dead fishes were found floating at the surface and some remained at an angle of $90^{\circ}$. Skin was pale and slime secretion was thick and yellowish. A mucous layer was also seen on the water surface.

The first visible reaction started within 25-30 minutes after exposure to the extracts of $A$. auriculaeformis seeds. The fishes rapidly moved up and down. After sometimes their movement slowed down and settled to the bottom and died at different intervals. Dead fishes showed less slime secretion, with slight mouth and opercular openings and skin showed signs of scar. Some of the fishes were seen in half floating condition and the rest remained at the bottom of the aquaria.

After exposure to the seed extracts of $P$. pinnata, the fishes showed vigorous erratic movements. At times they moved to the surface to gulp air. Fishes were stupefied within 30 minutes of exposure and gradually settled down. Dead fishes were seen with large mouth opening, wavy barbels and straight fins. Some of the dead fishes remained at the bottom with their ventral side directing upwards and few fishes were found floating at $90^{\circ}$ angle.

After releasing the fishes into the seed extracts of $A$. catechu, the fishes began to move up and down rapidly and were repeatedly raising towards the surface for taking air. Such movement continued for a while. Then the fishes failed to keep their balance, as a result their movement slowed down. At last they settled to the bottom and ultimately died at intervals. Slime secretion after death was seen. At times dead fishes were seen floating at an angle of $45^{\circ}$ but in most cases fishes sank down to the bottom of the aquaria.

On exposure to the toxicants, the fishes became restless with quick surfacing, agitated swimming and rapid opercular movement. Gradually they became balanceless, stupefied and died at various intervals with characteristic changes in their fins, barbels, mouth and skin. The characteristics observed in the dead and stiffened fishes were mainly mucous secretion and the nature of death as some fishes laid flat at the bottom of the aquaria, some were seen floating at angles of $45^{\circ}$ or $90^{\circ}$ or floating above and parallel to the water surface. Such behavioural pattern was also recorded by Latifa et al. 1987, 1988 and Nasiruddin et al. 1997, 1998, 2006. Excited swimming behaviour in Salmo gairdnerii was observed by Wedmeyer (1970). Agitated swimming behaviour of 


\section{TOXIC RESPONSE OF HETEROPNEUSTES FOSSILIS}

Pseudapocryptes dentatus, Gambusia affinis and Aphinis mento was also observed by Sharma et al. (1978). Bennet and Dooley (1982) regarded mucous secretion as defensive and excretory response whereas increased opercular movement is associated with loss of efficiency in oxygen uptake and decreasing physiological demand (James 1990). However, an increase in the toxic or concentration level caused a decrease in induction time of total equilibrium in the species and behavioural aspects were pronounced in more toxic extracts.

\section{Toxicological effects of the seed extracts on mortality of the fishes}

The result of percentage mortality of $H$. fossilis was recorded at an interval of $24 \mathrm{~h}$ of exposure to different concentrations of the seed extracts. A particular concentration of an extract caused a particular percentage of mortality and accordingly the experimental concentrations showed 10-90\% mortality (Table 1). Concentrations of the extracts varied with the plant toxicity. Probit analysis was used to determine the $\mathrm{LC}_{50}$ values with their confidence limits and chi-square and F- tests were done to determine the results of toxicity for each type of extracts (Table 2).

\section{The relative toxicities of the seed extracts}

The relative potency values of the seed extracts for $H$. fossilis are given in Table 3. Amongst the extracts absolute ethyl alcohol extract of A. rohituka seeds was the most toxic having $\mathrm{LC}_{50}$ value of $8.67 \mathrm{ppm}$ and high relative potency value of 224.92. The least toxic extract was the distilled water extract of D. innoxia with a $\mathrm{LC}_{50}$ value of $1950.03 \mathrm{ppm}$ and relative potency value of 1.00 . Fifty percent and absolute ethyl alcohol extracts of $C$. viscosum and $P$. pinnata and distilled water and $50 \%$ ethyl alcohol extracts of $A$. rohituka seeds were toxic with good $\mathrm{LC}_{50}$ values of $96.28,36.04,91.76,54.97,43.90$ and $18.38 \mathrm{ppm}$ respectively. Distilled water extracts of $C$. viscosum and $P$. pinnata and $50 \%$ and absolute ethyl alcohol extracts of $A$. auriculaeformis seeds were moderately toxic having $\mathrm{LC}_{50}$ values of 128.04, 217.67, 449.24 and 231.98 ppm respectively. Absolute ethyl alcohol extracts of $D$. innoxia and $A$. catechu and distilled water extract of $A$. auriculaeformis seeds were fairly toxic with $\mathrm{LC}_{50}$ values of $799.80,757.74$ and 668.87 ppm respectively. Fifty percent ethyl alcohol extracts of $D$. innoxia and A. catechu seeds were less toxic $\left(\mathrm{LC}_{50}=1337.73\right.$ and $\left.1341.99 \mathrm{ppm}\right)$ whilst distilled water extracts of the same seeds were the least toxic $\left(\mathrm{LC}_{50}=1950.03\right.$ and $1645.80 \mathrm{ppm}$ ) (Table 3). On the basis of $\mathrm{LC}_{50}$ and relative potency values the relative position of the extracts are as follows: 
MUNIRA NASIRUDDIN ET AL.

TABLE 1. PERCENTAGE MORTALITIES IN HETEROPNEUSTES FOSSILIS AT CONCENTRATIONS OF THE DIFFERENT EXTRACTS OF DATURA INNOXIA, CLERODENDRUM VISCOSUM, AMOORA ROHITUKA, ACACIA AURICULAEFORMIS, PONGAMIA PINNATA AND ACACIA CATECHU SEEDS AFTER 24 HOURS EXPOSURE.

\begin{tabular}{|c|c|c|c|c|c|c|c|}
\hline Plant seed & Extract & $\begin{array}{l}\text { Concen- } \\
\text { tration } \\
(\mathrm{ppm})\end{array}$ & $\begin{array}{l}\text { Mortality } \\
(\%) \text { of } H \text {. } \\
\text { fossilis }\end{array}$ & Plant & Extract & $\begin{array}{l}\text { Concen } \\
\text {-tration } \\
\text { (ppm) }\end{array}$ & $\begin{array}{l}\text { Mortality } \\
\text { (\%) of } H \text {. } \\
\text { fossilis }\end{array}$ \\
\hline \multirow{3}{*}{$\begin{array}{l}\text { Datura } \\
\text { innoxia }\end{array}$} & $\begin{array}{l}\text { Distilled } \\
\text { water }\end{array}$ & $\begin{array}{l}1000 \\
1500 \\
2000 \\
2500 \\
3000\end{array}$ & $\begin{array}{l}20 \\
30 \\
50 \\
60 \\
80\end{array}$ & \multirow{3}{*}{$\begin{array}{l}\text { Acacia } \\
\text { auriculaeformis }\end{array}$} & Distilled water & $\begin{array}{l}250 \\
500 \\
750 \\
1000 \\
1250\end{array}$ & $\begin{array}{l}10 \\
40 \\
50 \\
70 \\
80\end{array}$ \\
\hline & $\begin{array}{l}50 \% \\
\text { ethyl alcohol }\end{array}$ & $\begin{array}{l}500 \\
1000 \\
1500 \\
2000 \\
2500\end{array}$ & $\begin{array}{l}10 \\
40 \\
50 \\
70 \\
90\end{array}$ & & $\begin{array}{l}50 \% \\
\text { ethylalcohol }\end{array}$ & $\begin{array}{l}125 \\
250 \\
500 \\
750 \\
1000\end{array}$ & $\begin{array}{l}20 \\
30 \\
50 \\
60 \\
80\end{array}$ \\
\hline & $\begin{array}{l}\text { Absolute } \\
\text { ethyl alcohol }\end{array}$ & $\begin{array}{l}250 \\
500 \\
1000 \\
1500 \\
2000\end{array}$ & $\begin{array}{l}10 \\
30 \\
50 \\
80 \\
90\end{array}$ & & $\begin{array}{l}\text { Absolute ethyl } \\
\text { alcohol }\end{array}$ & $\begin{array}{l}50 \\
125 \\
250 \\
500 \\
750\end{array}$ & $\begin{array}{l}10 \\
30 \\
50 \\
70 \\
90\end{array}$ \\
\hline \multirow{3}{*}{$\begin{array}{l}\text { Clerodendrum } \\
\text { viscosum }\end{array}$} & $\begin{array}{l}\text { Distilled } \\
\text { water }\end{array}$ & $\begin{array}{l}50 \\
100 \\
150 \\
200 \\
250\end{array}$ & $\begin{array}{l}10 \\
40 \\
50 \\
70 \\
90\end{array}$ & \multirow{3}{*}{$\begin{array}{l}\text { Pongamia } \\
\text { pinnata }\end{array}$} & Distilled water & $\begin{array}{l}50 \\
100 \\
250 \\
500 \\
750\end{array}$ & $\begin{array}{l}20 \\
40 \\
50 \\
60 \\
80\end{array}$ \\
\hline & $\begin{array}{l}50 \% \\
\text { ethyl alcohol }\end{array}$ & $\begin{array}{l}25 \\
50 \\
100 \\
150 \\
200\end{array}$ & $\begin{array}{l}10 \\
30 \\
50 \\
60 \\
80\end{array}$ & & $\begin{array}{l}50 \% \text { ethyl } \\
\text { alcohol }\end{array}$ & $\begin{array}{l}25 \\
50 \\
150 \\
200 \\
250\end{array}$ & $\begin{array}{l}20 \\
40 \\
50 \\
70 \\
80\end{array}$ \\
\hline & $\begin{array}{l}\text { Absolute } \\
\text { ethyl alcohol }\end{array}$ & $\begin{array}{l}5 \\
25 \\
50 \\
100 \\
150\end{array}$ & $\begin{array}{l}20 \\
40 \\
50 \\
70 \\
80\end{array}$ & & $\begin{array}{l}\text { Absolute ethyl } \\
\text { alcohol }\end{array}$ & $\begin{array}{l}10 \\
25 \\
50 \\
100 \\
150\end{array}$ & $\begin{array}{l}10 \\
30 \\
50 \\
60 \\
80\end{array}$ \\
\hline \multirow{3}{*}{$\begin{array}{l}\text { Amoora } \\
\text { rohituka }\end{array}$} & $\begin{array}{l}\text { Distilled } \\
\text { water }\end{array}$ & $\begin{array}{l}5 \\
25 \\
50 \\
75 \\
100\end{array}$ & $\begin{array}{l}10 \\
30 \\
50 \\
60 \\
80\end{array}$ & \multirow{3}{*}{ Acaciacatechu } & Distilled water & $\begin{array}{l}1000 \\
1500 \\
2000 \\
2500 \\
3000\end{array}$ & $\begin{array}{l}20 \\
40 \\
60 \\
80 \\
90\end{array}$ \\
\hline & $\begin{array}{l}50 \% \\
\text { ethyl alcohol }\end{array}$ & $\begin{array}{l}5 \\
10 \\
25 \\
50 \\
75\end{array}$ & $\begin{array}{l}20 \\
30 \\
50 \\
80 \\
90\end{array}$ & & $\begin{array}{l}50 \% \text { ethyl } \\
\text { alcohol }\end{array}$ & $\begin{array}{l}500 \\
1000 \\
1500 \\
2000 \\
2500\end{array}$ & $\begin{array}{l}10 \\
30 \\
50 \\
70 \\
90\end{array}$ \\
\hline & $\begin{array}{l}\text { Absolute } \\
\text { ethyl alcohol }\end{array}$ & $\begin{array}{l}1 \\
5 \\
10 \\
25 \\
50\end{array}$ & $\begin{array}{l}10 \\
30 \\
50 \\
80 \\
90\end{array}$ & & $\begin{array}{l}\text { Absolute ethyl } \\
\text { alcohol }\end{array}$ & $\begin{array}{l}250 \\
500 \\
1000 \\
1500 \\
2000\end{array}$ & $\begin{array}{l}10 \\
30 \\
60 \\
80 \\
90\end{array}$ \\
\hline
\end{tabular}




\section{TOXIC RESPONSE OF HETEROPNEUSTES FOSSILIS}

TABLE 2: TOXICITY PARAMETERS OF THE DIFFERENT EXTRACTS OF DATURA INNOXIA, CLERODENDRUM VISCOSUM, AMOORA ROHITUKA, ACACIA AURICULAEFORMIS, PONGAMIA PINNATA AND ACACIA CATECHU SEEDS ON HETEROPNEUSTES FOSSILIS AFTER 24 HOURS EXPOSURE.

\begin{tabular}{|c|c|c|c|c|c|c|c|c|c|c|}
\hline \multirow[t]{2}{*}{ Plant } & \multirow[t]{2}{*}{ Solvent } & \multirow{2}{*}{$\begin{array}{l}\text { Dose } \\
\text { range } \\
(\mathrm{ppm})\end{array}$} & \multirow{2}{*}{$\begin{array}{l}\chi^{2} \\
\text { value }\end{array}$} & \multirow{2}{*}{$\begin{array}{l}\mathrm{P}- \\
\text { value } \\
\left(\chi^{2}\right) \\
\text { at } 5 \%\end{array}$} & \multirow{2}{*}{$\begin{array}{l}\text { F- } \\
\text { value }\end{array}$} & \multirow{2}{*}{$\begin{array}{l}\mathrm{P}- \\
\text { value } \\
\text { (F- } \\
\text { test) } \\
\text { at } 1 \%\end{array}$} & \multirow{2}{*}{$\begin{array}{l}\text { Estimated } \\
\text { regression } \\
\text { equation }\end{array}$} & \multirow{2}{*}{$\begin{array}{l}\mathrm{LC}_{50} \\
(\mathrm{ppm})\end{array}$} & \multicolumn{2}{|c|}{ Confidence limit } \\
\hline & & & & & & & & & Lower & Upper \\
\hline $\begin{array}{l}\text { Datura } \\
\text { innoxia }\end{array}$ & $\begin{array}{l}\text { Distilled } \\
\text { water } \\
50 \% \\
\text { ethyl alcohol } \\
\text { Absolute } \\
\text { ethyl alcohol }\end{array}$ & $\begin{array}{l}1000- \\
3000 \\
500- \\
2500 \\
250- \\
2000\end{array}$ & $\begin{array}{l}4.41 \\
7.30 \\
7.10\end{array}$ & $\begin{array}{l}\mathrm{P}> \\
0.05 \\
\mathrm{P}> \\
0.05 \\
\mathrm{P}> \\
0.05\end{array}$ & $\begin{array}{r}14.25 \\
15.83 \\
14.00\end{array}$ & $\begin{array}{l}\mathrm{P}< \\
0.01 \\
\mathrm{P}< \\
0.01 \\
\mathrm{P}< \\
0.01\end{array}$ & $\begin{array}{l}-5.86+3.30 x \\
-5.18+3.27 x \\
-2.88+2.72 x\end{array}$ & $\begin{array}{l}1950.03 \\
1337.73 \\
799.80\end{array}$ & $\begin{array}{l}1409.83 \\
904.85 \\
526.98\end{array}$ & $\begin{array}{l}2781.36 \\
1903.76 \\
1145.65\end{array}$ \\
\hline $\begin{array}{l}\text { Clerodendrum } \\
\text { viscosum }\end{array}$ & $\begin{array}{l}\text { Distilled water } \\
50 \% \\
\text { ethyl alcohol } \\
\text { Absolute } \\
\text { ethyl alcohol }\end{array}$ & $\begin{array}{l}50- \\
250 \\
25- \\
200 \\
5- \\
150\end{array}$ & $\begin{array}{r}7.98 \\
4.07 \\
6.92\end{array}$ & $\begin{array}{l}P> \\
0.05 \\
P> \\
0.05 \\
P> \\
0.05\end{array}$ & $\begin{array}{l}10.00 \\
12.17 \\
14.25\end{array}$ & $\begin{array}{l}\mathrm{P}> \\
0.01 \\
\mathrm{P}< \\
0.01 \\
\mathrm{P}< \\
0.01\end{array}$ & $\begin{array}{l}-1.68+3.16 x \\
0.78+2.12 x \\
3.62+0.88 x\end{array}$ & $\begin{array}{l}128.04 \\
96.28 \\
36.04\end{array}$ & $\begin{array}{l}89.13 \\
59.73 \\
11.00\end{array}$ & $\begin{array}{l}172.44 \\
165.33 \\
90.55\end{array}$ \\
\hline $\begin{array}{l}\text { Amoora } \\
\text { rohituka }\end{array}$ & $\begin{array}{l}\text { Distilled water } \\
50 \% \\
\text { ethyl alcohol } \\
\text { Absolute } \\
\text { ethyl alcohol }\end{array}$ & $\begin{array}{l}- \\
100 \\
5- \\
75 \\
1- \\
50\end{array}$ & $\begin{array}{l}6.93 \\
6.72 \\
4.88\end{array}$ & $\begin{array}{l}\mathrm{P}> \\
0.05 \\
\mathrm{P}> \\
0.05 \\
\mathrm{P}> \\
0.05\end{array}$ & $\begin{array}{l}12.17 \\
15.50 \\
14.00\end{array}$ & $\begin{array}{l}\mathrm{P}< \\
0.01 \\
\mathrm{P}< \\
0.01 \\
\mathrm{P}< \\
0.01\end{array}$ & $\begin{array}{l}2.5+1.51 x \\
2.76+1.77 x \\
3.69+1.41 x\end{array}$ & $\begin{array}{l}43.90 \\
18.38 \\
08.67\end{array}$ & $\begin{array}{l}21.61 \\
09.59 \\
04.16\end{array}$ & $\begin{array}{l}92.54 \\
31.66 \\
16.26\end{array}$ \\
\hline $\begin{array}{l}\text { Acacia } \\
\text { auriculaeformis }\end{array}$ & $\begin{array}{l}\text { Distilled water } \\
50 \% \\
\text { ethyl alcohol } \\
\text { Absolute } \\
\text { ethyl alcohol }\end{array}$ & $\begin{array}{l}250- \\
1250 \\
125- \\
1000 \\
50- \\
750\end{array}$ & $\begin{array}{l}4.47 \\
8.04 \\
4.72\end{array}$ & $\begin{array}{l}\mathrm{P}> \\
0.05 \\
\mathrm{P}> \\
0.05 \\
\mathrm{P}> \\
0.05\end{array}$ & $\begin{array}{l}12.50 \\
14.25 \\
10.00\end{array}$ & $\begin{array}{l}\mathrm{P}< \\
0.01 \\
\mathrm{P}< \\
0.01 \\
\mathrm{P}> \\
0.01\end{array}$ & $\begin{array}{l}-3.87+3.16 \mathrm{x} \\
-0.09+1.92 \mathrm{x} \\
0.26+2.00 \mathrm{x}\end{array}$ & $\begin{array}{r}668.87 \\
449.24 \\
231.98\end{array}$ & $\begin{array}{r}452.42 \\
238.26 \\
\\
135.22\end{array}$ & $\begin{array}{r}951.88 \\
899.60 \\
384.33\end{array}$ \\
\hline $\begin{array}{l}\text { Pongamia } \\
\text { pinnata }\end{array}$ & $\begin{array}{l}\text { Distilled water } \\
50 \% \\
\text { ethyl alcohol } \\
\text { Absolute } \\
\text { ethyl alcohol }\end{array}$ & $\begin{array}{l}50- \\
750 \\
25- \\
250 \\
10- \\
150\end{array}$ & $\begin{array}{l}6.92 \\
8.91 \\
10.13\end{array}$ & $\begin{array}{l}\mathrm{P}> \\
0.05 \\
\mathrm{P}> \\
0.05 \\
\mathrm{P}< \\
0.05\end{array}$ & $\begin{array}{r}25.00 \\
24.24 \\
12.17\end{array}$ & $\begin{array}{l}\mathrm{P}< \\
0.01 \\
\mathrm{P}< \\
0.01 \\
\mathrm{P}< \\
0.01\end{array}$ & $\begin{array}{l}1.92+1.31 \mathrm{x} \\
2.17+1.44 \mathrm{x} \\
2.64+1.41 \mathrm{x}\end{array}$ & $\begin{array}{l}217.67 \\
91.76 \\
54.97\end{array}$ & $\begin{array}{l}79.08 \\
37.08 \\
29.95\end{array}$ & $\begin{array}{r}582.46 \\
189.26 \\
110.87\end{array}$ \\
\hline $\begin{array}{l}\text { Acacia } \\
\text { catechu }\end{array}$ & $\begin{array}{l}\text { Distilled water } \\
50 \% \\
\text { ethyl alcohol } \\
\text { Absolute } \\
\text { ethyl alcohol }\end{array}$ & $\begin{array}{l}1000- \\
3000 \\
500- \\
2500 \\
250- \\
2000\end{array}$ & $\begin{array}{l}2.73 \\
7.69 \\
1.39\end{array}$ & $\begin{array}{l}\mathrm{P}> \\
0.05 \\
\mathrm{P}> \\
0.05 \\
\mathrm{P}> \\
0.05\end{array}$ & $\begin{array}{l}4.55 \\
10.00 \\
3.77\end{array}$ & $\begin{array}{l}\mathrm{P}> \\
0.01 \\
\mathrm{P}> \\
0.01 \\
\mathrm{P}> \\
0.01\end{array}$ & $\begin{array}{l}-8.97+4.35 x \\
-5.63+3.40 x \\
-3.02+2.79 x\end{array}$ & $\begin{array}{l}1645.80 \\
1341.99 \\
757.74\end{array}$ & $\begin{array}{l}1212.72 \\
963.05 \\
497.37\end{array}$ & $\begin{array}{r}2029.34 \\
1789.79 \\
1073.70\end{array}$ \\
\hline
\end{tabular}


Absolute ethyl alcohol extract of $A$. rohituka seeds $>50 \%$ ethyl alcohol extract of $A$. rohituka seeds $>$ Absolute ethyl alcohol extract of $C$. viscosum seeds $>$ Distilled water extract of $A$. rohituka seeds > Absolute ethyl alcohol extract of $P$. pinnata seeds $>50 \%$ ethyl alcohol extract of $P$. pinnata seeds $>50 \%$ ethyl alcohol extract of $C$. viscosum seeds $>$ Distilled water extract of $C$. viscosum seeds $>$ Distilled water extract of $P$. pinnata seeds $>$ Absolute ethyl alcohol extract of $A$. auriculaeformis seeds $>50 \%$ ethyl alcohol extract of $A$. auriculaeformis seeds > Distilled water extract of $A$. auriculaeformis seeds > Absolute ethyl alcohol extract of $A$. catechu seeds $>$ Absolute ethyl alcohol extract of $D$. innoxia seeds $>50 \%$ ethyl alcohol extract of $D$. innoxia seeds $>50 \%$ ethyl alcohol extract of $A$. caetchu seeds $>$ Distilled water extract of $A$. catechu seeds $>$ Distilled water extract of $D$. innoxia seeds.

All the extracts were more or less toxic with variations in concentrations. Due to the effects of different concentrations mortality rate of the fishes varied. In the present study in terms of concentration, $\mathrm{LC}_{50}$ and relative potency values the toxic effects of the plants followed the order A. rohituka $>C$. viscosum $>P$. pinnata $>$ A. auriculaeformis $>$ A. catech $>>D$. innoxia seed extracts. Chi- square values showed most of the data to be insignificant excepting absolute ethyl alcohol extract of $P$. pinnata seeds indicating a good relationship between observed and expected mortalities. Analysis of data made between mortality and concentrations showed that most of the analyses were significant at 0.01 level which again indicated a good relationship between the concentrations used and mortalities obtained.

In the present study, The $\mathrm{LC}_{50}$ values of distilled water, $50 \%$ ethyl alcohol and absolute ethyl alcohol extracts of the six plant seeds on $H$. fossilis were 1950.03, 1337.73 and $799.80 \mathrm{ppm}$ (D. innoxia), 128.04, 96.28 and $36.04 \mathrm{ppm}(C$. viscosum), 43.90, 18.38 and $8.67 \mathrm{ppm}$ (A. rohituka), 668.87, 449.24 and 231.98 ppm (A. auriculaeformis), 217.67, 91.76 and 54.97 ppm (P. pinnata) and 1645.80, 1341.99 and $757.74 \mathrm{ppm}$ (A. catechu) respectively. Latifa et al. (1992) obtained the $\mathrm{LC}_{50}$ values of 289.068 and $102.094 \mathrm{ppm}$ for $50 \%$ ethyl alcohol and absolute ethyl alcohol extracts of $M$. ferrea seeds on $H$. fossilis. Nasiruddin et al. (1997) obtained the $\mathrm{LC}_{50}$ values of distilled water and $50 \%$ ethyl alcohol extracts of $A$. indica seed kernels on $H$. fossilis as 710.598 and 500.337 ppm respectively. The $\mathrm{LC}_{50}$ values of distilled water and $50 \%$ ethyl alcohol extracts on the same fish were 33.647 and $24.810 \mathrm{ppm}$ (A. procera seed), 41.398 and $25.019 \mathrm{ppm}(S$. mahagoni seed kernel), 85.304 and 48.429 ppm ( $S$. multiflora seed) and 805.061 and $381.646 \mathrm{ppm}$ (S. indicum seed kernel), respectively (Nasiruddin et al. 1998). 
TOXIC RESPONSE OF HETEROPNEUSTES FOSSILIS

TABLE 3: THE LC $_{50}$, RELATIVE POTENCY VALUES AND RANGE OF TOXICITIES OF THE DIFFERENT EXTRACTS OF DATURA INNOXIA, CLERODENDRUM VISCOSUM, AMOORA ROHITUKA, ACACIA AURICULAEFORMIS, PONGAMIA PINNATA AND ACACIA CATECHU SEEDS ON HETEROPNEUSTES FOSSILIS AFTER 24 HOURS EXPOSURE.

\begin{tabular}{|c|c|c|c|c|}
\hline Plant seed & Extract & $\begin{array}{l}\mathrm{LC}_{50} \\
(\mathrm{ppm})\end{array}$ & $\begin{array}{l}\text { Relative } \\
\text { potency }\end{array}$ & Range of toxicity \\
\hline $\begin{array}{l}\text { Datura } \\
\text { innoxia }\end{array}$ & $\begin{array}{l}\text { Distilled water } \\
50 \% \text { ethyl alcohol } \\
\text { Absolute ethyl } \\
\text { alcohol }\end{array}$ & $\begin{array}{l}1950.03 \\
1337.73 \\
799.80\end{array}$ & $\begin{array}{l}1.00 \\
1.46 \\
2.44\end{array}$ & $\begin{array}{l}\text { Least toxic } \\
\text { Less toxic } \\
\text { Fairly toxic }\end{array}$ \\
\hline $\begin{array}{l}\text { Clerodendrum } \\
\text { viscosum }\end{array}$ & $\begin{array}{l}\text { Distilled water } \\
50 \% \text { ethyl alcohol } \\
\text { Absolute ethyl } \\
\text { alcohol }\end{array}$ & $\begin{array}{l}128.04 \\
96.28 \\
36.04\end{array}$ & $\begin{array}{l}15.23 \\
20.25 \\
54.11\end{array}$ & $\begin{array}{l}\text { Moderately toxic } \\
\text { Toxic } \\
\text { Toxic }\end{array}$ \\
\hline $\begin{array}{l}\text { Amoora } \\
\text { rohituka }\end{array}$ & $\begin{array}{l}\text { Distilled water } \\
50 \% \text { ethyl alcohol } \\
\text { Absolute ethyl } \\
\text { alcohol }\end{array}$ & $\begin{array}{l}43.90 \\
18.38 \\
8.67\end{array}$ & $\begin{array}{l}44.42 \\
106.10 \\
224.92\end{array}$ & $\begin{array}{l}\text { Toxic } \\
\text { Toxic } \\
\text { Most toxic }\end{array}$ \\
\hline $\begin{array}{l}\text { Acacia } \\
\text { auriculaeformis }\end{array}$ & $\begin{array}{l}\text { Distilled water } \\
50 \% \text { ethyl alcohol } \\
\text { Absolute ethyl } \\
\text { alcohol }\end{array}$ & $\begin{array}{l}668.87 \\
449.24 \\
231.98\end{array}$ & $\begin{array}{l}2.92 \\
4.34 \\
8.41\end{array}$ & $\begin{array}{l}\text { Fairly toxic } \\
\text { Moderately toxic } \\
\text { Moderately toxic }\end{array}$ \\
\hline $\begin{array}{l}\text { Pongamia } \\
\text { pinnata }\end{array}$ & $\begin{array}{l}\text { Distilled water } \\
50 \% \text { ethyl alcohol } \\
\text { Absolute ethyl } \\
\text { alcohol }\end{array}$ & $\begin{array}{l}217.67 \\
91.76 \\
54.97\end{array}$ & $\begin{array}{l}8.96 \\
21.25 \\
35.47\end{array}$ & $\begin{array}{l}\text { Moderately toxic } \\
\text { Toxic } \\
\text { Toxic }\end{array}$ \\
\hline $\begin{array}{l}\text { Acacia } \\
\text { catechu }\end{array}$ & $\begin{array}{l}\text { Distilled water } \\
50 \% \text { ethyl alcohol } \\
\text { Absolute ethyl } \\
\text { alcohol }\end{array}$ & $\begin{array}{l}1645.80 \\
1341.99 \\
757.74\end{array}$ & $\begin{array}{l}1.18 \\
1.45 \\
2.57\end{array}$ & $\begin{array}{l}\text { Least toxic } \\
\text { Less toxic } \\
\text { Fairly toxic }\end{array}$ \\
\hline
\end{tabular}

Range of toxicity:

Most toxic

Toxic $\quad 10<100 \mathrm{ppm}$

Moderately toxic $100<500 \mathrm{ppm}$

Fairly toxic $500<1000 \mathrm{ppm}$

Less toxic

$1000<1500$ ppm

Least toxic $1500<2000 \mathrm{ppm}$ 
Whereas, the $\mathrm{LC}_{50}$ values of distilled water, $50 \%$ ethyl alcohol and absolute ethyl alcohol extracts were 1089.976, 642.632 and $566.565 \mathrm{ppm}$ for A. indica seed and 99.549, 42.506 and $18.767 \mathrm{ppm}$ for $B$. accutangula seed extracts (Nasiruddin et al. 2006). From the above findings it can be said that absolute ethyl alcohol extract of $A$. rohituka seed was the most toxic extract $\left(\mathrm{LC}_{50}=8.67 \mathrm{ppm}\right)$ and distilled water extract of $D$. innoxia seed was the least toxic $\left(\mathrm{LC}_{50}=1950.03\right.$ ppm).

From the present study it is observed that the toxic effect of $A$. rohituka seed extract was highly effective on $H$. fossilis. The effectivity of the seed extracts of $C$. viscosm, $P$. pinnata, A. auriculaeformis, A. catechu and D. innoxia seemed to be promising at different dose levels. The six indigenous plant extracts analysed might be helpful as controlling agent of undesirable fish species in the nursery, rearing and stocking ponds of a fish culture farm. It is suggested that laboratory based toxicological studies of crude dry products can give optimal information about the effectivity of the plant toxins on the fish species.

\section{REFERENCES}

AMEEN, M. AND SHAHJAHAN, R.M. 1987. Lethal effect of Derris elliptica (Benth) root on the catfish Heteropneustes fossilis (Bloch). Bangladesh J. Agri. 12(1): 19-26.

AMEEN, M., SHIREEN, K.F., RAHMAN, P.K.M. AND AHMED, M.U. 1987. Effect of additives on the toxicity of different Derris root formulations on the catfish, Heteropneustes fossilis (Bloch). Dhaka University Studies, Pt E 2(2): 71-77.

AMERICAN PUBLIC HEALTH ASSOCIATION (APHA). 1976. Standard methods for the examination of water and waste water. APHA press, Washington DC 1193 pp.

BENNET, R.O. AND DOOLEY, J.K. 1982. Copper intake by two sympatric species of Fundulus heteroclitus and F. majalis (Walbann). J. Fish. Biol. 21: 381-398.

FINNEY, D.G.1971. Probit Analysis. $3^{\text {rd }}$ ed. Cambridge University Press, London 333 pp. HAQUE, M.F. AND TILTON, J.E. 1970. Note on the use of the Rotenone as a piscicide in ponds on the campus of Bangladesh Agricultural University. Sci. Res. 7: 111-113.

JAMES, R. 1990. Industrial and combined effects of heavy metals on behaviour and respiratory responses of Oreochromis mossambicus. Indian J. Fish. 37(2): 139-143. 
KONAR, S.K. 1970. Nicotine as a fish poison. Progr. Fish. Cult. 32: 103-104.

KONAR, S.K. 1977. Toxicity of Nicotine to aquatic life. Indian J. of Fisheries. 24: 124-128.

LATIFA, G.A. AND BEGUM, A. 1993. Piscicidal activity of the dry stem of Euphorbia neriifolia (Linn.) on Heteropneustes fossilis (Bloch) and Channa punctatus (Bloch). Bangladesh J. Sci. Res. 11(2): 217-225.

LATIFA, G.A., SHAFI, M., PARVIN, S.I. AND CHOWDHURY, A.K.A. 1987. Study on the piscicidal property of the fresh roots of Tephrosia purpurea on fishes, Heteropneustes fossilis and Channa punctatus. Dhaka Univ. Stud. Pt. E. 2(1): 13-21.

LATIFA, G.A., SHAFI, M., PARVIN, S.I., ALAM, M.J. AND AHMED, M. 1988.Piscicidal property of the dry roots of Tephrosia purpurea (Pers.) on Heteropneustes fossilis (Bloch) and Channa punctatus (Bloch). J. Asiatic Soc. Bangladesh (Sc). 14(1): 49-55.

LATIFA, G.A., AHSAN, M.F. AND SARKER, S.D. 1992. Piscicidal property of the fresh seeds of Mesua ferrea Linn. on Heteropneustes fossilis (Bloch). J. Asiatic Soc.Bangladesh Sc.18(1): 73-77.

LATIFA, G.A., BEGUM, S., AKHTER, A. and AHMED, M.S. 1997. Piscicidal properties of the dry barks of Azadirachta indica (A. Juss) on Heteropneustes fossilis (Bloch). Bangladesh J. Life Sci. 9(2): 31-36.

LATIFA, G.A., HAMID, A. AND SHARMA, G. 2002. Study of the piscicidal activity of dry bark of Diospyros ebenum (Koen) on Heteropneustes fossilis (Bloch) and Channa punctatus (Bloch). Bangladesh J. Life Sci. 14(1\&2): 107-118.

LATIFA, G.A., BACHAR, S.C. AND BEGUM, T. 2004. Piscicidal activity of the dry barks of Leucaena leucocephala (Lam De Wit) on Channa punctatus (Bloch) and Channa striatus (Bloch). Bangladesh J. Zool. 32(2): 247-251.

LENNON, R.E. AND BERGER, B.L. 1970. A resume on field application of Antimycin A to control fish. In: Investigation in fish control Report. US Dept. Inst. Fish and Wildl Serv. Bur. Report. Fish and Wildl. 40: $19 \mathrm{pp}$.

NASIRUDDIN, M., AZADI, M.A. CHOWDHURY, R. AND MAJUMDER, S.M.M.H. 1997. Piscicidal effects of seed kernel extracts and oil of seed kernels of Azadirachta indica A. Juss on two predatory fishes Heteropneustes fossilis (Bloch) and Anabus testudineus (Bloch). Chittagong Univ. Stud. Part II Sc. 21(1): 53- 62. 
MUNIRA NASIRUDDIN ET AL.

NASIRUDDIN, M., AZADI, M.A. AND CHOWDHURY, R. 1998. Piscicidal effects of seed and seed kernel extracts of four indigenous plants on Heteropneustes fossilis (Bloch) and Anabus testudineus (Bloch). The Chittagong University Journal of Science 22(2): 1-10.

NASIRUDDIN, M., AZADI, M.A., CHOWDHURY, R. AND SULTANA, M.N. 2006. Studies on the piscicidal properties of Azadirachta indica (A. Juss) and Barringtonia accutangula (Gaertn) plant parts on Heteropneustes fossilis (Bloch). Bangladesh J. Zool. 34(1): 95- 104.

SHARMA, K.P., Al-NASIRI, S.K. AND BHATTI, M.N. 1978. Toxicity and efficacy of MS-222 on three fishes of Iraq. Bangladesh J. Zool. 6(2): 107-112.

SHIRGUR, G.A. 1972. Development of indigenous Derris powder. Journal of the Indian Fisheries Association 2(1\&2): 55-59.

SHIRGUR, G.A. 1975. Indication of safe poison materials from indigenous plants for clearing unwanted fishes from nursery ponds. Indian J. of Fisheries 22 (1\&2):126-132.

WEDMEYER, G. 1970. Stress of anaesthesia with MS-222 and Benzocaine in rainbow trout (Salmo gairdneri). J. Fish. Res. Bd. Can. 27: 909-914.

Manuscript received on 25.10.08; Accepted on 12.4. 09

The Chittagong University Journal of Biological Sciences, Vol.4 ( 1 \& 2): Page No : 1-12 